University of Nebraska - Lincoln

DigitalCommons@University of Nebraska - Lincoln

Faculty Publications: Department of Teaching, Department of Teaching, Learning and Teacher Learning and Teacher Education

Education

2009

Living in the Space between Participant and Researcher as a

Narrative Inquirer: Examining Ethnic Identity of Chinese Canadian

Students as Conflicting Stories to Live By

Elaine Chan

Follow this and additional works at: https://digitalcommons.unl.edu/teachlearnfacpub

Part of the Curriculum and Instruction Commons, and the Teacher Education and Professional

Development Commons

This Article is brought to you for free and open access by the Department of Teaching, Learning and Teacher Education at DigitalCommons@University of Nebraska - Lincoln. It has been accepted for inclusion in Faculty Publications: Department of Teaching, Learning and Teacher Education by an authorized administrator of DigitalCommons@University of Nebraska - Lincoln. 


\title{
Living in the Space between Participant and Researcher as a Narrative Inquirer: Examining Ethnic Identity of Chinese Canadian Students as Conflicting Stories to Live By
}

\author{
Elaine Chan \\ College of Education and Human Sciences, University of Nebraska-Lincoln, Lincoln, Nebraska, USA \\ Corresponding author - Elaine Chan, Department of Teaching, Learning, and Teacher Education, College of Edu- \\ cation and Human Sciences, University of Nebraska-Lincoln, 24 Henzlik Hall, Lincoln, NE 68588-0355, email \\ echan2@unl.edu
}

\begin{abstract}
Schooling experiences of 1st-generation Canadians interact with cultural experiences in their immigrant households to shape a sense of ethnic identity both as Canadians and as members of an ethnic community. This long-term, school-based narrative inquiry is an examination of ways in which expectations for academic performance and behavior by teachers and peers at school and immigrant parents at home contributed to shaping the ethnic identity of an immigrant Chinese student as conflicting stories to live by. A narrative approach revealed challenges of supporting immigrant students in North American schools and contributed to understanding of the nuances of multicultural education.
\end{abstract}

Keywords: narrative inquiry, ethnic identity, curriculum, multicultural education, student experiences

For children, school has enormous implications for their sense of identity as members of society, of their families, and of their ethnic communities. Each individual brings to their school context experiences shaped by their participation in schools, whether in Canada or in their home country, whether positive or negative, enriching or demoralizing. For a child of immigrant parents, tensions between home and school, the interaction of parent and 
teacher experiences of schooling, and their own experiences of schooling may be felt especially strongly, to the point of being experienced as conflicting stories to live by (Connelly \& Clandinin, 1999). These students have their own ideas of how they should be in their school context, shaped by interaction with peers, exposure to popular culture and media, and prior experiences of schooling, schools, and teachers. At the same time, they are evaluated by teachers and supported by parents whose experiences of schooling may be vastly different, by nature of social and political influences as well as personal circumstances of the societies of which their own childhood schools were a part.

In the present study, I examined the experiences of one Chinese immigrant student, Ai Mei Zhang. I explore her participation in her Canadian middle school curriculum as the interaction of student, teacher, and parent narratives, a story of interwoven lives (Clandinin et al., 2006). I examined ways in which her sense of ethnic identity may be shaped by expectations for her academic performance and her behavior in her school and her home. I focus in particular on ways in which participation in her urban, multicultural school setting may contribute to shaping her sense of affiliation to family members and members of her ethnic and school communities, and contribute to her maternal-language development and maintenance. I also examined ways in which she experienced well-intended school practices and curriculum activities designed to support her academic performance in ways not anticipated by policymakers and educators. I explored these influences as conflicting stories to live by (Connelly \& Clandinin, 1999).

I examined experientially the intersection of school and home influences from the perspective of one middle school student as a long-term, school-based narrative inquirer. I explored features of narrative inquiry, such as the critical role of researcher-participant relationships, and the role of temporal and spatial factors (Clandinin \& Connelly, 2000) of the research context in contributing to a nuanced understanding of multicultural education in this diverse school context. The present study is holistic in that I examined the impact of multiple influences in a connected way as they intersected in the life of one student rather than as examples of ways in which an issue or theme may be experienced by different members of the same ethnic group.

Given the increasing diversity of the North American population (Statistics Canada, 2008; U.S. Census Bureau, 2002) that is in turn reflected in North American schools (Chan \& Ross, 2002; He, Phillion, Chan, \& Xu, 2007), addressing the curricular needs of students of minority background and supporting the professional development of teachers who work with them is essential. The present study contributes to existing research in the area of multicultural education and, in particular, curriculum development for diverse student populations, and student experiences of multicultural education.

To date, research addressing the interaction of culture and curriculum is often presented as an argument for the inclusion of culture in the school curriculum or as documentation for ways in which the inclusion of culture in the curriculum was successful (Ada, 1988; Cummins et al., 2005). There is an abundance of research highlighting the importance of culturally relevant and responsive pedagogy (Gay, 2000; Ladson-Billings, 1995, 2001; Villegas, 1991) and a culturally sensitive curriculum that builds on the experiences and knowledge of immigrant and minority students (Ada; Cummins, 2001; Igoa, 1995; Nieto \& Bode, 2008). 
Acknowledging the cultural knowledge of minority students in the classroom has been found to have important implications for their well-being outside of school. For example, Banks (1995) highlighted the inclusion of culture in the curriculum as a means of helping students to develop positive racial attitudes. Rodriguez (1982), Wong-Fillmore (1991), and Kouritzin (1999) presented compelling accounts of ways in which the failure to support the maintenance and development of maternal-language proficiency for students of minority background had dire consequences for their sense of ethnic identity and their sense of belonging in their families and ethnic communities. McCaleb (1994), Cummins (2001), and Wong-Fillmore elaborated on some of the dangers, such as increased dropout rates among immigrant and minority youth as well as increased likelihood of gang involvement, or failing to recognize the cultural communities from which students come.

Existing research has been invaluable in highlighting the importance of acknowledging the cultural knowledge that immigrant and minority students bring to a school context, and thework of educators as they develop curricula and teach an increasingly diverse student population (Banks, 1995; Cummins, 2001; Moodley, 1995). Research has also accentuated the need to develop ways of learning about the ethnic, linguistic, and religious backgrounds of students to inform curriculum development and policymaking for students of diverse backgrounds. Cochran-Smith (1995), Ladson-Billings (1995, 2001), and Conle (2000) explored the practice of drawing on the cultural knowledge of preservice teachers as a resource for preparing them to teach in culturally diverse classrooms. It is interesting to note that although there is research that has acknowledged the potential difficulties of moving from home to school for students of a minority background, and the difficulties of moving from school back home when minority students have assimilated to the school and societal expectations that differ from those of their home cultures, the day-to-day transition as minority and immigrant students move from home to school and back home again seems to have been overlooked. In the present study, I examine the nuances that one student lives as she makes this transition on a daily basis.

This work addresses the need for experiential research, focusing specifically on exploring the intersection of home and school influences from the perspective of the students themselves. Presently, there is a surprising lack of research examining ways in which students, in general (Cook-Sather, 2002), and immigrant and minority students, in particular, personally experience their school curriculum and school contexts (He et al., 2007). Bullough's (2007) examination of a Muslim student's response to curriculum and peer interactions in hisU.S. school is among the few pieces examining school-curriculum activities from the perspective of a student of ethnic-minority background. Feuerverger's (2001) ethnographic work exploring tensions that Israeli and Palestinian youth experience in their IsraeliPalestinian school is among few studies documenting and exploring student perspectives of their schooling experiences. Sarroub (2005) and Zine's (2001) accounts ofMuslim students in American and Canadian schools, respectively, illustrate the complexities of negotiating a sense of identity among peers in a school context when values in the home differ significantly.

Within the relatively limited body of existing research addressing student experiences of schooling and curriculum presented, I present examples of student experiences thematically to address specific issues, topics, or arguments rather than ways that acknowledge 
multiple facets and tensions interacting at once to shape the experiences of an individual student. Smith-Hefner (1993), in her ethnographic study of female high school Khmer students, presented examples of Puerto Rican female students whose limited academic success was shaped by cultural and sociohistorical influences in their ethnic communities. RolonDow (2004) examined tensions Puerto Rican students and their teachers experience when values supported in their home and in their ethnic communities seem to conflict with those encouraged in school. Lee's $(1994,1996)$ ethnographic study focused on ways in which Asian high school students' sense of identity and academic achievement was influenced by self-identified labels and membership in specific peer groups. There does not exist a large body of research examining the experiences of one student in the context of theirNorth American school in a way that presents the stories to illustrate ways in which the interaction of multiple influences and issues of relevance may impact on an immigrant or minority student.

This narrative inquiry is intended to provide a glimpse of the intersection of complex influences shaping the life of an immigrant student. I drew on existing narrative and ethnographic accounts of immigrant and minority students attending North American schools to inform this work. Vald'es's (1996) work documenting the experiences of a small number of Latino and Mexican American families in their school and community and Li's (2002) ethnographic study with Chinese families as they supported their children's literacy development provide a glimpse of ways in which transitions between home and school may be challenging, and even overwhelming, due to differences in expectations about the school curriculum and the work of teachers. Carger's (1996) long-term narrative account of aMexican American family's experiences provides an organizational structure for the present study, in that it is an in-depth account of one family's experiences of supporting their child in school, taking into consideration the intersection ofmultiple influences shaping the child's education. Ross \& Chan's (2008) narrative account of an immigrant student, Raj, and his family's academic, financial, and familial difficulties highlighted the many challenges the family encountered in the process of supporting their children's adaptation to their Canadian school and community. This examination of Ai Mei's experiences contributes to the growing but still limited body of research addressing Chinese students in North American schools (Chan, 2004; Kao, 1995; Kim \& Chun, 1994; Lee, 1994, 1996, 2001; Li, 2002, 2005).

\section{Theoretical Framework}

Given the focus on experience in contributing toAiMei's sense of ethnic identity, I used Dewey's (1938) philosophy of the interconnectedness between experience and education as the theoretical foundation for this study. I examined, in particular, ways in which the many influences in her home, school, and neighborhood life with family members, peers, teachers, administrators, and school curriculum events intersected to contribute to her overall experience or learning of a sense of ethnic identity as an immigrant student in a Canadian school context. Ai Mei's stories are set into the framework of a three-dimensional narrative inquiry space (Clandinin \& Connelly, 2000), with Bay Street School as the spatial dimension, the years 2001-2003 as the temporal dimension, and my interactions with Ai Mei, her classmates, her teachers, her parents, and other members of the Bay Street School 
community as the sociopersonal dimension. The stories are a means of exploring the interaction of influences contributing to Ai Mei's sense of identity; they highlight the extent to which this intersection of narratives may be interpreted as conflicting stories to live by (Connelly \& Clandinin, 1999).

\section{Method}

I first met Ai Mei when I began observations in her seventh-grade class as a classroombased participant observer for a research project exploring the ethnic identity of firstgeneration Canadian students. The focus on examining the intersection of culture and curriculum as experienced by Chinese Canadian students over the course of their 2 years in middle school was deliberate from the beginning. As I learned about the details of the students' experiences, the complex interaction of factors contributing toAi Mei's sense of ethnic identity became apparent and merited further analysis.

Ai Mei's homeroom teacher, William, told me about how she had arrived at Bay Street School from an urban area of Fuchien province in China as a 7-year-old. Although she did not initially speak English at all, she was relatively proficient by the time I met her $4 \frac{1}{2} 2$ years after her arrival.Her English was distinct from that of her native-English-speaking peers by the unusual turns of phrases and unconventional uses of some words, but the animated way in which she spoke about her experiences caught my attention from the beginning. I later appreciated this quality even more as I began to work more closelywith her as a research participant. Her dark eyes, partially hidden behind wisps of hair, seemed to flicker and dance as she elaborated on details of interactions with peers and family members, especially when she recounted amusing or troublesome events pertaining to difficulties she had experienced in communicating with others. She also seemed to enjoy telling me about incidents that had occurred at home, at school, or in the community. As I learned about Ai Mei's stories of immigration and settlement, the conflicting influences and expectations of her family members, peers and teachers at school, and members of her ethnic community became more apparent, thus further contributing to my decision to focus on her stories in this study.

As a narrative inquirer, I learned about Ai Mei's stories of experience (Connelly \& Clandinin, 1988) using a variety of narrative approaches, including long-term, school-based participant observations, document collection set into the context of ongoing conversational interviews with key participants, and the writing of extensive field notes following each school visit, interview, and interaction with participants (Clandinin \& Connelly, 1994, 2000; Clandinin et al., 2006) to explore the interwoven quality of Ai Mei, her teacher, her classmates, and her family members' lives. I observed and interacted with her in the context of regular classroom lessons as I assisted her and her classmates with assignments, accompanied them on field trips, attended their band concerts and performances, and took part in school activities such as Multicultural Night, Curriculum and Hot Dog Night, school assemblies, and festivals. School visits began during the fall of 2001 as Ai Mei and her classmates began seventh grade and continued until June 2003 when they graduated from eighth grade at Bay Street School. 
I conducted interviews as well as ongoing informal conversations with Ai Mei over the course of the 2 years I spent in her homeroom classroom. I also collected documents such as school notices, announcements of community and school events, notices from bulletin boards and classroom walls in the school, agendas and minutes from School Council meetings, and samples of student work. Descriptive field notes, interview transcripts, researcher journals, and theoretical memos written following school visits were computerized and filed into an existing research project archival system. I examined field notes pertaining to Ai Mei's experiences numerous times to identify recurring themes. Her stories were set into the context of field notes written about her classroom teacher, her peers, and her school community since I began research at the school in 2000.

\section{Results}

\section{Ai Mei's Stories of Home and School: Conflicting Stories to Live By}

I subsequently present some of Ai Mei's stories of experience to explore challenges and complexities, harmonies and tensions (Clandinin \& Connelly, 2002), she lived as she attempted to balance affiliation to her peers while at the same time accommodating for expectations placed on her by her teachers and parents. I explore ways in which parent, teacher, and peer expectations may contribute to shaping her sense of identity, and examine the contribution of narrative methodology in revealing nuances of the intersection of multiple influences in her life.

\section{Bay Street School Context}

Ai Mei's stories were set in the context of Bay Street School, a school known to consist of a diverse student community from the time of its establishment (Cochrane, 1950; Connelly, He, Phillion, Chan, \& Xu, 2004), located in an urban Toronto neighborhood where the ethnic composition of residents is known to reflect Canadian immigration and settlement patterns (Connelly, Phillion, \& He, 2003). Accordingly, the student population at the school reflects this diversity. An Every Student Survey administered to students during the 20012002 school year (Chan \& Ross, 2002) confirmed the ethnic and linguistic diversity of the students. More specifically, 39 countries and 31 languages were represented in the school. This was the context in which Ai Mei's stories played out.

\section{Home Language Conflicting with School Language}

I subsequently present the story "I was trying to hide my identity" as a starting point for examining Ai Mei's experiences of her academic program at Bay Street School.

"I was trying to hide my identity"

Ai Mei: When I first came to Bay Street School, I stayed with the IL (International Language $)^{1}$ teacher, Mrs. Lim ... I stayed with her for the whole week, and she taught me things in English.

Elaine: What did she teach you? 
Ai Mei: You know, easy things, like the alphabet, and how to say "Hello." Then I went to Ms. Jenkins' class. I sat with a strange boy.

Elaine: A strange boy?

Ai Mei: Well, he wasn't that strange. My desk was facing his desk, and he did this to me (Ai Mei demonstrates what the boy did), he stuck his tongue out at me. I didn't know what it meant. He had messy orange hair.

Elaine: Did you make any friends?

Ai Mei: No, not for a long time. Some people tried to talk to me but I didn't understand them. Then Chao tried to talk with me in Fujianese and I pretended I didn't understand her. She tried a few times, then gave up. Then one day, my sister said something to me in Fujianese and Chao heard. She looked at me-she was really surprised because she tried to talk with me and I pretended I couldn't understand her. She didn't like me at all.

Elaine: Why did you do that? Why did you pretend you couldn't understand her?

Ai Mei: I don't know. I was trying to hide my identity.

Ai Mei: (calling over to Chao) Chao, remember how I didn't talk with you, how I pretended I didn't understand you?

Chao: Yeah, I remember. (Chao scowls at Ai Mei.) I didn't like you for a long time.

Ai Mei: Yeah, a long time.

(Field notes, April, 2003)

When Ai Mei arrived at Bay Street School, new students coming into the school spent a week or two with the respective International Language (IL) teacher prior to placement into a classroom. The new student orientation provided teachers the opportunity to assess the English and maternal-language proficiency of new students, identify potential learning difficulties, and learn about their previous schooling experiences. The orientation also provided students an opportunity to learn about school routines in their home language while being gradually introduced into their age-appropriate classroom.

Ai Mei's response to the new student orientation, however, was surprising for a number of reasons. From her teachers' perspective, Chao would have seemed like an ideal friend for Ai Mei-both girls were from the same rural province of southern China, grew up speaking Fujianese at home and Mandarin in school, and Chao could helpAiMei to adapt to Bay Street School because she had arrived two years earlier. However, Ai Mei did not seem to welcome the opportunity to speak with Chao in Fujianese. Her teachers were also likely puzzled that she would try to "hide [her] identity," because, from their perspective, they worked hard to create programs that would acknowledge students' home cultures in a positive way.

In this context, it is possible that Ai Mei, similar to many students featured in research on immigrant and minority students (Cummins, 2001; Kouritzin, 1999), perceived her 
affiliation to her family's home language as a hindrance to acceptance by English-speaking peers. She seemed to appreciate learning English from her IL teacher and perhaps felt that her inability to speak in English was an obstacle to forming friendships with Englishspeaking peers. One day, as we were walking back to her homeroom classroom after art class, she has told me about an incident when she felt embarrassed when she attempted to order drinks at a shopping mall and the vendor could not understand her because "[her] English accent was so bad!" Ai Mei may have been attempting to distance herself from those she perceived as non-English-speaking when she said she "tried to hide [her] identity." Wong-Fillmore (1991) elaborated on how a language minority child might abandon the home language when she or he realizes the low status of this language in relation to the English that is used by peers in school. At the same time, in choosing not to respond to her Fujianese-speaking classmate who attempted to befriend her, Ai Mei was giving up the opportunity to make a friend at a time when she did not have the English proficiency to build friendships easily with English-speaking peers.

\section{School Language Conflicting with Home Language}

In addition to pressure to achieve a higher level of English proficiency, Ai Mei seemed to be under pressure from her IL Mandarin teacher, Mrs. Lim, to maintain and to develop her Mandarin proficiency. She was in a high level of language within her grade-level Mandarin program,${ }^{2}$ and she was doing well in the class, judging from the grades I saw when she showed me her Mandarin language textbook and workbooks. Her teacher has said that she did well in her assignments and tests, and that she was a strong student in Mandarin. She stated that it was important for Ai Mei to work hard to maintain the advantage she had over her Canadian-born Chinese peers. Mrs. Lim believed that Ai Mei has an easier time learning the characters that many Canadian-born Chinese students have difficulty with, due to her early years of schooling in China before arriving in Canada. She also felt that Ai Mei had an advantage over her Chinese-born peers, in that her schooling prior to leaving China was regular and uninterrupted in a way some of her Chinese-born peers had not experienced.

Maintenance of her Mandarin language proficiency is an achievement her parents support. At the same time, they would like her to maintain fluency in her family's home dialect of Fujianese. For Ai Mei and her parents, maternal language maintenance has important implications for communication within the family. Ai Mei told me about the following mealtime conversation involving her mother and her younger sister, Susan.

"Susan doesn't speak Fujianese"

Ai Mei: We were eating supper and my mother said to my sister, "(phrase in Fujianese)." My sister asked me, "What did she say?" so I told her, "She wants to know if you want more vegetables."

Elaine: Your sister doesn't understand Fujianese?

Ai Mei: She does but not everything.

Elaine: What did your mother say? Is she worried that your sister doesn't understand her? 
Ai Mei: She looked at her like this-(Ai Mei showed me how her mother gave her sister a dirty look).

(Field notes, April, 2003)

From the field note, it seems that Ai Mei's parents were beginning to feel the effects of maternal language loss within the family. Fujianese is not easy to develop and maintain because its use in Canada is not widely supported outside the home, with the exception of exposure to the dialect through other recent immigrants from Fuchien Province. Susan's inability to understand basic vocabulary in her home language likely worried her and Ai Mei's parents, but given the limited resources to support it and limited time to encourage her themselves, they might wonder what can be done. Ai Mei spoke about how her parents reminded her often to speak with her sister in Fujianese. Meanwhile, the sisters had long grown into the habit of speaking to one another in English; communication in their home language of Fujianese would have been stifled at that point due to the lack of ease both felt in using it as well as Susan's limited vocabulary. It might be the case that their parents, as they began to realize the extent of their daughter's maternal language loss, might already be too late to stop it. This pressure to develop and to maintain language proficiency interacted with other factors contributing to Ai Mei's sense of identity and affiliation in her school and in her home and ethnic communities.

\section{Parent Values Conflicting with Peer Values}

In addition to pressure to succeed academically, Ai Mei was also under pressure to behave according to the expectations of her peers, teachers, and parents. Through interaction with Ai Mei at Bay Street School over the course of two full academic years, it became apparent that being included within her peer group was very important to her. Like her peers, Ai Mei was becoming more firmly entrenched into popular movies, music, and fashion trends as she moved into adolescence. These influences were coupled with increasing pressure from peers to scoff at school success and downplay the importance of academic work. During the fall of 2001, there were a number of days when I arrived at Ai Mei's classroom to find her friends trying to console her after a popular and outspoken male classmate, Felix, had made unflattering comments about her appearance. Her homeroom teacher also told me about incidents when she had left school in tears after being excluded from an after school activity that had been planned by classmates. Another day, I overheard Felix mimicking one of the stories from Ai Mei's Mandarin IL text; although he spoke in English, the tone and storyline were along the lines of what might be found in the text. Ai Mei laughed at Felix's attempts and seemed to appreciate that he knew a little about what she did in IL class, but I also wondered whether she was embarrassed or annoyed with him.

In addition to concerns about being excluded by her peers and feeling the pull of multiple influences in school to behave in certain ways, Ai Mei also seemed to live the tensions of parental expectations and standards for her behavior and comportment that, at times, conflicted with those of her peers, and ways in which she saw herself. I wrote the following field note after a conversation with Ai Mei in which she complained about her mother's comments about her in relation to her mother's friend during a family outing. 
"Dim Sum with her mother's friend"

Ai Mei told me today about going out to dim sum with her mother's friend and her family. She said she was very annoyed at being compared to her mother's friend's daughter who is close in age to Ai Mei but who seems like a perfect daughter in her mother's eyes. Ai Mei told me, "My mother said, 'Look at Ming Ming, so pretty and tall. And so quiet! She helps her mother do the cooking and the cleaning at home.' She said to Ming Ming's mother, 'Look at Ai Mei, 13 years old and so short. And she doesn't help me at home, and she doesn't cook!' She kept comparing us, saying how nice Ming Ming is and how terrible I am." Ai Mei rolled her eyes.

(Field notes, April, 2003)

The interaction between Ai Mei and her mother highlighted the potential for tensions to develop when expressing differences in perspective about the value of certain kinds of behaviors over others. It sounded as if Ai Mei resented that her mother did not think she was quiet or helpful or tall enough when compared with her friend's daughter. Although a generational gap might account for some of the tension about what constituted appropriate behavior and goals for Ai Mei with respect to what she did to contribute to the family, some of this tension might also have been shaped by the very different contexts in which Ai Mei and her mother have spent their childhood. Ai Mei has spent a good portion of her childhood living in different homes in an urban, commercial district of Toronto. Her perception of appropriate behavior and practices has likely been shaped by influences different from what her mother experienced in rural Fuchien province of China where she spent her own childhood.

\section{Teacher Expectations Conflicting with Parent Expectations}

Moreover, although Ai Mei's parents and her teachers had in common the goal of academic success for her, tensions surfaced about the time commitment needed to fulfill these school and family responsibilities. Ai Mei seemed to be caught between pressures to help in the family business and teacher expectations for completed homework and thorough preparation for tests and assignments.

Ai Mei's family acquired a dumpling restaurant during the fall of her eighth-grade year, and since then, the whole family had devoted much time and energy toward building a successful business. I knew that Ai Mei's family owned a dumpling restaurant because she had told me about what she did to help.

Ai Mei: There's a door that no one can close but me.

Elaine: What's wrong with it?

Ai Mei: It's stuck, so I have to kick it shut. (She demonstrates as she says this, kicking to one side as she leans over.) Then, we go home, me, my mom, and my dad.

Elaine: How about your sister?

Ai Mei: She goes home a little earlier, with my grandmother and grandfather.

(Field notes, October, 2002) 
Each day after school, Ai Mei and her sister, Susan, after spending some time with their friends in the classroom or in the school yard, headed to the dumpling restaurant to spend the evening there helping their parents. Ai Mei's sister, Susan, has told me about how she helped their father by standing outside the restaurant where the family sells vegetables and fruits to watch for people who attempted to take food without paying for it. When I asked her whether this often happened, she nodded gravely.

The importance of Ai Mei and Susan's participation in the family business could be denied, but Ai Mei's teachers had questioned the time commitment involved. Late in the fall after the family acquired the dumpling restaurant, Ai Mei's teacher,William, noticed that she had begun to come to school looking very tired, and without her homework done. One day while he was meeting with her to discuss the report card that would soon be sent home to her parents, he told her that she could have done better had she submitted all of her homework and done a better job on recent tests. Ai Mei surprised him by bursting into tears. Little by little, William learned that Ai Mei had little opportunity to do her homework or to study because she was helping out at the restaurant during evenings and weekends. By the time the family had closed up the restaurant, traveled home, and eaten supper, it was past 11:00 p.m. or 12:00 a.m., beyond what William thought was appropriate for a 12-year-old. With a sense of professional responsibility to report potentially negligent situations to officials and the support of school board policies guiding his actions, William spoke with his principal about the situation. Both decided it was a borderline case, and with the principal's knowledge, William contacted the Children's Aid Society (CAS) about Ai Mei's family. I wrote the following field note the day William told me about his call to the CAS.

\section{"I called the CAS"}

I was helping William straighten up the textbooks, sort student assignments into piles, and organize pens, pencils, and chalk into appropriate places in the classroom. We have gotten into the habit of talking about events of the day as we tidy up the classroom after the students have left for French class toward the end of the day. Today, William said to me, "I called the CAS about Ai Mei. She doesn't do her homework or have time to study because she's up late working in the family restaurant. She's exhausted."

(Field notes, December, 2002)

The dumpling restaurant was tied to Ai Mei's family's dreams of financial success and family reunification. Ai Mei had spoken about how her parents had sponsored her maternal grandparents to come toToronto from Fuchien province and were in the process of trying to bring her paternal grandparents over to join the family as well. The importance of helping her family with their business could not be denied from her parents' perspective and, from what Ai Mei has said about the ways in which she helped the family, it could be assumed that she also recognized the importance of her role as well.

At the same time, it was beginning to become apparent that assisting her parents in the family business might have diverted her attention away from fulfilling her parents' desire 
for her to do well in school, in that time spent in the restaurant helping her family was time that she could have otherwise devoted to her school work. Ai Mei was caught between her parents' dreams of financial and business success, her sense of responsibility, as the oldest daughter in the family, to help them achieve this success, her parents' desire for her to perform well academically to secure her own future economic success, and her teacher's professional responsibility to report potentially negligent situations to officials. She lived the tensions of deciding how best to use her time to assist her parents in the family business as well as to perform well academically.

This situation also needed to be examined in terms of her teacher's professional tensions and ways in which these tensions might have contributed to Ai Mei's sense of identity. Her teacher,William, was aware that the cultural and social narratives guiding his professional practices might have differed from those guiding the practices of the parents of his students, and had expressed a commitment to acknowledging the diversity of his students. The potential for conflict between teacher, student, and parent perspectives pertaining to AiMei's use of time in the evenings and on weekends became apparent when William contacted child-protection officials to report that Ai Mei's time in the family's restaurant in the evenings was contributing to her late arrival at school in the mornings, without her assigned homework completed. He did so with the belief in the importance of protecting Ai Mei's time to ensure that she had adequate time and necessary conditions in her home to complete her school work.

William's call to the CAS, however well intentioned, had the potential to cause difficulties in Ai Mei's family as well as a rift in his own relationship with Ai Mei. In fact, he later told me about how Ai Mei, on realizing that he had reported her parents to the CAS, neither came around after school to spend time in his classroom nor did she tell him about what was happening in her life as she was accustomed to doing up until that time. He felt he had lost her trust and believed that his call to the CAS had been the cause. This example highlights some of the tensionWilliam felt as he attempted to balance his professional obligation to report potentially negligent situations to child protection officials and his ideal of the role of teacher as an advocate who supported students in ways they would appreciate.

\section{Learning about Ai Mei's Experiences as a Narrative Inquirer}

These stories highlight some of the complexities of the interaction of multiple influences in contributing to Ai Mei's sense of identity. Underlying these accounts of Ai Mei's experiences with her peers, teachers, and parents in the context of school and community-based events are accounts of my interactions with Ai Mei as a narrative inquirer. The narrative inquiry approach used in this study facilitated the identification of the many nuances of living as an immigrant student in aNorth American school context, and provided a framework in which to ponder these complexities. To begin, the stories of experience documenting Ai Mei's experiences as an immigrant student at Bay Street School were gathered over a long period of time as I spent 2 full school years in her homeroom classroom with her, her teachers, and her peers as a participant observer. During this time, I became a member of the classroom, joining the class for activities such as field trips, special school events, band concerts, and school assemblies. More importantly, however, I was a part of their class during the uneventful days of lessons and regular school activities. It was during 
these times that I was able to build a relationship with Ai Mei and her peers and teachers. They grew to see me as an additional teacher in the classroom who was able to help them with assignments, act as an adult supervisor during in-school activities or field trips, and as a listening ear when they had disagreements with friends or with teachers.

I learned about the details of Ai Mei's life as she told me about her classmates, her parents, her family's dumpling restaurant, her sister, and family outings. I heard about her perceptions of how she fit into her peer group, her ethnic community, and her family as she told me about specific interactions, such as the family dinner when her sister did not understand what her mother had said in Fujianese, her mother's criticisms of her in comparison with her mother's friend's daughter, or her impressions of the new student orientation that was in place to ease her transition into the school as a new student from China.

As the students came to realize my interest in learning about their school lives, they began to update me on events I had missed between visits, and to fill me in on what they referred to as "gossip" at school. At one point partway through my second year with Ai Mei's homeroom class, I conducted interviews with the students. As I planned the questions and discussed them with William, I remember wondering whether this shift to a more formal kind of interaction with the students would change the relationship we had established. My concern about negatively impacting the relationship turned out to be unfounded. In fact, I was pleased to realize one day when Ai Mei approached me to tell me about a family dinner (see "Susan doesn't speak Fujianese") that the process had opened up further opportunities to learn about the students' lives. Realizing that I was interested in hearing about their interactions at home and in the community with members of their ethnic groups, the students began to tell me more about them. Our existing relationship had provided a foundation such that I could talk with the students about their experiences with family and members of their ethnic communities, and the interviews provided an opportunity for the students to learn, in a more explicit way, about my interest in hearing about out-of-school aspects of their lives. Our relationship was such that they knew they could trust that I would treat their stories and their perceptions of these stories with interest and respect.

I also saw Ai Mei in the neighborhood with her friends during the after school hours as they moved from house to house visiting one another in the housing project while their parents worked in nearby restaurants and shops, and on weekends as she shopped with her sister and her parents in the stores that lined the commercial area near the school. These brief interactions provided further glimpses of influences interacting in her life to contribute to shaping a sense of identity in ways that would not be possible through formal interviews or a more structured schedule of research observations. In addition, these interactions provided an opportunity for Ai Mei's friends and family to become familiar with my presence and participation in the school.

Tensions of acting as a researcher with a focus on learning about the experiences of my participants became more apparent as my role as researcher became less clear. As I got to know Ai Mei and her family, I felt the tensions she experienced as she balanced the multiple influences in her life and wanted to advocate for her. I felt a sense of responsibility to Ai Mei, to support her learning and to attempt to ease some of the tensions she experienced as she balanced affiliation to her home and school cultures. I understood a little of the 
betrayal she felt when her parents were reported to child protection officials, and the fear her parents might have felt. When she told me about how her parents would not be able to attend her eighth-grade graduation because they needed to work, I wanted to be sure to attend and to take photos of her with her sister so that she would have a record of the event. The nature of the researcher-participant relationship in contributing to understanding about the nuances of experiences lived by my student participant heightened my understanding of what the events might mean for her.

The role of narrative inquiry, and, more specifically, the role of long-term participation in the day-to-day school life of an immigrant student that was critical to this narrative inquiry, contributed to the researcher-participant relationship I was able to develop with Ai Mei, her peers, and her teachers. Careful attention to the details of life in classrooms (Jackson, 1990) and within the school, and respect for the ongoing negotiation so critical to building a research relationship from initial negotiation of entry into the school research site to negotiation of exit toward the completion of school-based narrative inquiries - features foundational to Clandinin \& Connelly's (2000) approach - further contributed to the development of a research relationship based on trust and familiarity with Ai Mei. This trust, in turn, engaged me in careful consideration of the potential implications of telling and retelling Ai Mei's stories, and what they might mean for her, as well as other immigrant and minority students who may struggle with similar challenges of balancing tensions of affiliation to home and school cultures in aNorth American school context. It was also through this commitment to examining these tensions narratively from multiple perspectives of others in Ai Mei's school, as well as in relation to temporal, spatial, and sociopersonal dimensions at play in her school, that enabled me to see some of the nuances and complexities of the conflicting influences in Ai Mei's life. In the process of examining Ai Mei's experiences narratively, I also became a participant, in that my experiences and interpretations of Ai Mei's stories were continually being examined and reflected on as I shared my interpretations with Ai Mei in an ongoing process to better understand the stories she told.

This relationship, in turn, was critical to my learning about the complexities of Ai Mei's experiences. In this way, this long-term, school-based narrative inquiry approach contributes not only to knowledge about the experiences of my participants as I focus on examining nuances of the research phenomenon at hand but also raises awareness about the intricacies, and the impact, of the work of researchers in the lives of our participants.

\section{Discussion}

\section{Conflicting Student, Teacher, and Parent Stories to Live By: Implications for Practice,} Research, and Theory

This examination of the intersection of home, school, and ethnic community influences in Ai Mei's life provided a glimpse of the challenges immigrant or minority students might encounter as they negotiate a sense of ethnic identity. More specifically, examining Ai Mei's stories reveals ways in which immigrant and minority students may be pulled in many directions, with some of these influences experienced as conflicting stories to live by as teacher, peer, and parent expectations intersect on a school landscape. The stories high- 
light the potential for conflict when immigrant students have values shaped by interaction with family and members of their ethnic community as well as values shaped by interaction with peers, teachers, and other members of their North American school communities.

As Ai Mei grows up, she needs to determine which aspects of her home and school communities she incorporates into her own set of values. The age-old tension between children and their parents as children move toward adulthood and make decisions pertaining to their education and the kind of life they see themselves leading is exacerbated by differences in perspective that are influenced by differences in culture between their new host society that the children are navigating and the landscape that their immigrant parents experienced as children in their home countries. This tension is further complicated by struggles that their parents have endured in the immigration process as they settle into new countries. Ai Mei's stories revealed the extent to which ideas for innovative curricula and the good intentions of teachers, administrators, researchers, and policymakers may unfold in unexpected ways. Learning about Ai Mei's conflicting stories to live by highlighted the importance of examining ways in which curriculum and school events may contribute to shaping the ethnic identity of immigrant and minority students in ways much more complex than anticipated by their teachers, their parents, and even the students themselves.

This knowledge, in turn, informs the work of teachers and administrators as they attempt to meet the needs of their increasingly diverse student populations. Teachers need to learn to meet the academic and social needs of their immigrant and minority students in a school context with sometimes little knowledge about the cultures and education systems from which they are coming. In this way, knowledge gained from this study has implications for teachers working in diverse school contexts, professional development for in-service and pre-service educators, and decision making pertaining to the development of curriculum policies for multicultural school contexts. Examining Ai Mei's experiences of the intersection of home and school influences informs the development and implementation of programs designed to facilitate the adaptation of immigrant students in North American schools. Ai Mei's stories of experience may be referred to as an example of a lifebased literary narrative (Phillion \& He, 2004) and contribute to the body of student lore introduced by Schubert and Ayers (1992) and recognized by Jackson (1992) in Pinar, Reynolds, Slattery, and Taubman's book, Understanding Curriculum (1995). Attention to the narratives of students and their families is a reminder not to lose sight of the diversity in student populations and highlights the need for attention to issues of social justice and equity in education. Not only does this research address the dearth of research focused specifically on students' experiences from their perspective but it also contributes to understanding of the experiences of immigrant and minority students to provide insights into the experiences of a group about which educators and policymakers involved in developing and implementing school curriculum are desperately in need of better understanding.

\section{Conclusion}

Teachers and administrators with whom I shared this piece appreciated the acknowledgment of the challenges they encounter in their work with their students. William, as a 
beginning teacher, recognized the need for further attention to prepare teachers for diverse classrooms and felt that stories such as those presented in this article contributed to raising awareness of difficulties teachers may encounter; he recognized the potential of the stories as a forum to generate discussion among teachers and administrators. His administrators spoke of the challenges inherent to meeting the needs of their student population and referred to the tensions of needing to abide by existing policies even as they lived the difficulties of implementing some of the policies with their students and teachers.

Exploring the multitude of influences shaping student participation in school curriculum using a narrative inquiry approach to examining student experiences is also a means of acknowledging the complexity of schooling and teacher preparation (Cochran Smith, 2006), and the need for guidance about how best to develop curriculum and pedagogy for students ofminority background, and the challenges associated with working with diverse student populations. Given the increasingly diverse North American context, it is essential that educators and policymakers are well informed about the students for whom educational practices and policies are developed.

\section{Notes}

1. Students at Bay Street School chose from IL classes in Cantonese or Mandarin Chinese, Vietnamese, Arabic, Swahili/Black History, or Spanish that were integrated into their regular school day.

2. The Mandarin texts used in the IL program were based on a multigrade format in which each grade level was in turn divided into six levels of difficulty ranging from beginner to advanced to accommodate for differences in language proficiency among students in the same grade level.

\section{References}

Ada, A. F. (1988). The Pajaro Valley experience: Working with Spanishspeaking parents to develop children's reading and writing skills in the home through the use of children's literature. In T. Skutnabb-Kangas \& J. Cummins (Eds.), Minority education: From shame to struggle (pp. 223-237). Clevedon, UK: Multilingual Matters.

Banks, J. A. (1995). Multicultural education: Its effects on students' racial and gender role attitudes. In J. A. Banks \& C. A. McGee Banks (Eds.), Handbook of research on multicultural education (pp. 617627). Toronto, Canada: Prentice Hall International.

Bullough, R. V. Jr. (2007). Ali: Becoming a student-A life history. In D. Thiessen \& A. Cook-Sather (Eds.), International handbook of student experience in elementary and secondary school (pp. 493-516). Dordecht, The Netherlands: Springer.

Carger, C. (1996). Of borders and dreams: Mexican-American experience of urban education. New York: Teachers College Press.

Chan, E. (2004). Narratives of ethnic identity: Experiences of first generation Chinese Canadian students. Unpublished doctoral dissertation, University of Toronto, Ontario, Canada.

Chan, E., \& Ross, V. (2002). ESL Survey Report. Sponsored by the ESL Workgroup in collaboration with the OISE/UT Narrative and Diversity Research Team. Toronto, Canada: Centre for Teacher Development, Ontario Institute for Studies in Education, University of Toronto, Ontario, Canada. 
Clandinin, D. J., \& Connelly, F. M. (1994). Personal experience methods. In N. K. Denzin \& Y. S. Lincoln (Eds.), Handbook of qualitative research in the social sciences (pp. 413-427). Thousand Oaks, CA: Sage.

Clandinin, D. J., \& Connelly, F. M. (2000). Narrative inquiry: Experience and story in qualitative research. San Francisco: Jossey-Bass.

Clandinin, D. J., \& Connelly, F. M. (2002, October). Intersecting narratives: Cultural harmonies and tensions in inner-city urban Canadian schools. Proposal submitted to the Social Sciences and Humanities Research Council of Canada.

Clandinin, D. J., Huber, J., Huber, M., Murphy, M. S., Murray Orr, A., Pearce, M., et al. (2006). Composing diverse identities: Narrative inquiries into the interwoven lives of children and teachers. New York: Routledge.

Cochrane, M. (Ed.). (1950). Centennial story: Board of education for the city of Toronto: 1850-1950. Toronto, Canada: Thomas Nelson.

Cochran-Smith, M. (1995). Uncertain allies: Understanding the boundaries of race and teaching. Harvard Educational Review, 65, 541-570.

Cochran-Smith, M. (2006). Thirty editorials later: Signing off as editor. Journal of Teacher Education, 57(2), 95-101.

Conle, C. (2000). The asset of cultural pluralism: an account of crosscultural learning in pre-service teacher education. Teaching and Teacher Education, 16, 365-387.

Connelly, F. M., \& Clandinin, D. J. (1988). Teachers as curriculum planners: Narratives of experience. New York: Teachers College Press.

Connelly, F. M., \& Clandinin, D. J. (1999). Stories to live by: Teacher identities on a changing professional knowledge landscape. In F. M. Connelly \& D. J. Clandinin (Eds.), Shaping a professional identity: Stories of educational practice (pp. 114-132). London, Canada: Althouse Press.

Connelly, F. M., He, M. F., Phillion, J., Chan, E., \& Xu, S. (2004). Bay Street Community School: Where you belong. Orbit, 34(3), 39-42.

Connelly, F. M., Phillion, J., \& He, M. F. (2003). An exploration of narrative inquiry into multiculturalism in education: Reflecting on two decades of research in an inner-city Canadian community school. Curriculum Inquiry, 33, 363-384.

Cook-Sather, A. (2002) Authorizing students' perspectives: toward trust, dialogue, and change in education. Educational Researcher, 31(4), 3-14.

Cummins, J. (2001). Negotiating identities: Education for empowerment in a diverse society (2nd ed.). Ontario, CA: CABE (California Association for Bilingual Education).

Cummins, J., Bismilla, V., Chow, P., Cohen, S., Giampapa, F., Leoni, L., et al. (2005). Affirming identity in multilingual classrooms. Educational Leadership, 63(1), 38-43.

Dewey, J. (1938). Experience and education. New York: Simon \& Schuster.

Feuerverger, G. (2001). Oasis of dreams: Teaching and learning peace in a Jewish-Palestinian village in Israel. New York: Routledge.

Gay, G. (2000). Culturally responsive teaching: Theory, research, E practice. New York: Teachers College Press.

He, M. F., Phillion, J., Chan, E., \& Xu, S. (2007). Chapter 15-Immigrant students' experience of curriculum. In F. M. Connelly, M. F. He, \& J. Phillion (Eds.), Handbook of curriculum and instruction (pp. 219-239). Thousand Oaks, CA: Sage.

Igoa, C. (1995). The inner world of the immigrant child. New York: St. Martin's Press.

Jackson, P. (1990). Life in classrooms. New York: Teachers College Press. 
Jackson, P. (1992). Conceptions of curriculum specialists. In P. Jackson (Ed.), Handbook of research on curriculum (pp. 3-40). New York: Peter Lang.

Kao, G. (1995). Asian Americans as model minorities? A look at their academic performance. American Journal of Education, 103, 121-159.

Kim, U., \& Chun, M. J. B. (1994). The educational 'success' of Asian Americans: An indigenous perspective. Journal of Applied Developmental Psychology, 15, 329-339.

Kouritzin, S. G. (1999). Face(t)s of first language loss. Mahwah, NJ: Erlbaum.

Ladson-Billings, G. (1995). Multicultural teacher education: Research, practice, and policy. In J. A. Banks \& C. A. McGee Banks (Eds.), Handbook of research on multicultural education (pp. 747-759). Toronto, Canada: Prentice Hall International.

Ladson-Billings, G. (2001). Crossing over to Canaan: The journey of new teachers in diverse classrooms. San Francisco: Jossey-Bass.

Lee, S. J. (1994). Behind the model-minority stereotype: Voices of high- and low-achieving Asian American students. Anthropology \& Education Quarterly, 25, 413-429.

Lee, S. J. (1996). Unraveling the "model minority" stereotype: Listening to Asian American youth. New York: Teachers College Press.

Lee, S. J. (2001). More than "model minority" or "delinquents": A look at Hmong American high school students. Harvard Educational Review, 71, 505-528.

Li, G. (2002). “East is East, West is West”? Home literacy, culture, and schooling. In J. L. Kincheloe \& J. A. Jipson (Eds.), Rethinking childhood book series (Vol. 28). New York: Peter Lang.

Li, G. (2005). Culturally contested pedagogy: Battles of literacy and schooling between mainstream teachers and Asian immigrant parents. Albany, NY: SUNY Press.

McCaleb, S. P. (1994). Building communities of learners: A collaboration among teachers, students, families and community. New York: St. Martin's Press.

Moodley, K. A. (1995). Multicultural education in Canada: Historical development and current status. In J. A. Banks \& C. A. McGee Banks (Eds.), Handbook of research on multicultural education (pp. 801-820). Toronto, Canada: Prentice Hall International.

Nieto, S., \& Bode, P. (2008). Affirming diversity: The sociopolitical context of multicultural education (5th ed.). New York: Longman.

Phillion, J., \& He, M. F. (2004). Using life-based literary narratives in multicultural teacher education. Multicultural Perspectives, 6(2), 3-9.

Pinar, W. F., Reynolds, W. M., Slattery, P., \& Taubman, P. M. (1995). Understanding curriculum: An introduction to the study of historical and contemporary curriculum discourses. New York: Peter Lang.

Rodriguez, R. (1982). Hunger of memory: The education of Richard Rodriguez. Boston: David R. Godine.

Rolon-Dow, R. (2004). Seduced by images: Identity and schooling in the lives of Puerto Rican girls. Anthropology \& Education Quarterly, 35, 8-29.

Ross, V., \& Chan, E. (2008). Multicultural education: Raj's story using a curricular conceptual lens of the particular. Teaching and Teacher Education, 24, 1705-1716.

Sarroub, L. K. (2005). All-American Yemeni girls: Being Muslim in a public school. Philadelphia: University of Pennsylvania Press.

Schubert, W., \& Ayers, W. (Eds.) Teacher lore: Learning from our own experience. New York: Longman.

Smith-Hefner, N. (1993). Education, gender, and generational conflict among Khmer refugees. Anthropology \& Education Quarterly, 24, 135-158.

Statistics Canada. (2008). Canada's ethnocultural mosaic, 2006 census. Retrieved July 1, 2008, from http://www12.statcan.ca/english/census06/analysis/ethnicorigin/pdf/97-562-XIE2006001.pdf 
U.S. Census Bureau. (2002). United States Census 2000. Washington, D.C: U.S. Government Printing Office.

Valdés,G. (1996). Con respeto: Bridging the distances between culturally diverse families and schools. An ethnographic portrait. New York: Teachers College Press.

Villegas, A. M. (1991). Culturally responsive pedagogy for the 1990's and beyond. Princeton, NJ: Educational Testing Service.

Wong-Fillmore, L. (1991). When learning a second language means losing the first. Early Childhood Research Quarterly, 6, 323-346.

Zine, J. (2001). Muslim youth in Canadian schools: Education and the politics of religious identity. Anthropology \& Education Quarterly, 32, 399-423.

\section{Author Note}

Elaine Chan is an assistant professor of Diversity and Curriculum Studies in the Department of Teaching, Learning, and Teacher Education at the College of Education and Human Sciences, the University of Nebraska-Lincoln. Her research and teaching interests are in the areas of narrative inquiry, culture and curriculum, multicultural education, ethnic identity of first-generation North Americans, student experiences of schooling, and educational equity policies. She has taught and conducted long-term classroom-based research in Canadian, Japanese, and American schools. She is currently coauthoring a book on engaging ELL students in arts education with Margaret Macintyre Latta. 